[A]人工的に砂闻渴度がー一定に保たれた埸合は水蒸 氮密度差は不鼠となり，渢速の影響は㨁接にきけて來 る.この上き蒸發影は抄面の前線よりの距離 $x$ と風速に

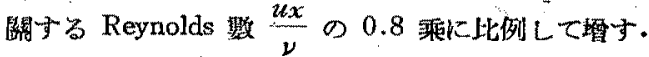

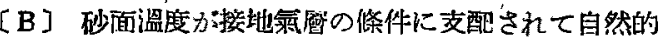

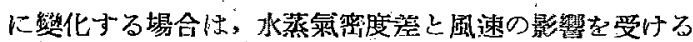
ので，砂面温度 $\theta$ ，名外妞溫上等しく，砂面上りの放熱

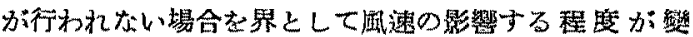
了. 即古

(1) 砂面の輻射吸收熱量が大で $\theta_{:}>\theta_{0}$ のときは砂 间上り外氣中への放熱加風速に㕍じて行われ， $\theta_{s}$ の上 昇务制合に小さく，從つて水蒸氯密既差が小さくなるの

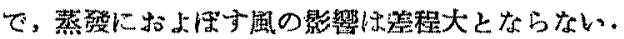

(2) $\theta_{s}<\theta_{1}$ の場合には砂面はかへつて外氣上bo㖟
められ，その程度は風速と共に增すので水蒸氣滵度裙は

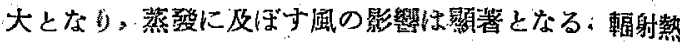
の吸收省体わむいときはこの場合だ，冬でも風の强い日

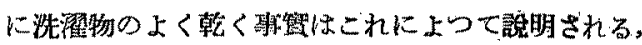

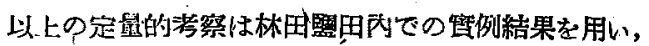

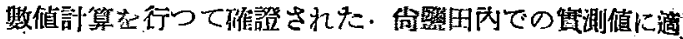

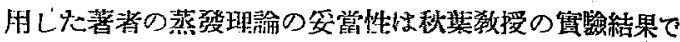

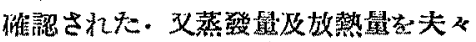

$$
E=\frac{a}{\rho}\left(c_{n}-c_{1}\right), \quad H_{k}=h\left(\theta_{z}-\theta_{1}\right)
$$

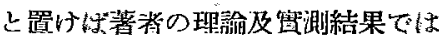

$$
\frac{h}{a}=\frac{a}{a^{1}} c p=0.3 \quad \mathrm{~K} \mathrm{cal}, \mathrm{lgg}^{9} \mathrm{C}
$$

となりりこれは Shepherdなどの篮澌結果と一致し， I.ewis の結果をも立證し得ること起した。

\title{
噴露式製鹽法に關する理論
}

(蒸發の研究 第 4 翢)

川原 㴍 磨2

\section{A Theory on the Manufacture of Salt}

by spraing. (Studies on Evaporation. $4^{\text {th }}$. Report)

by. Takuma. Kawahara.

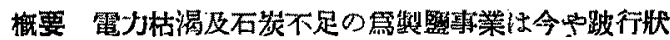

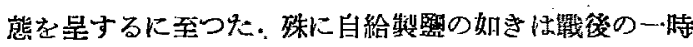

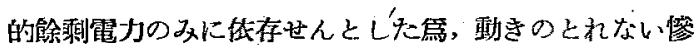

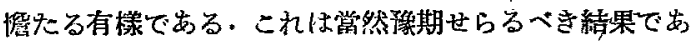
D\%.

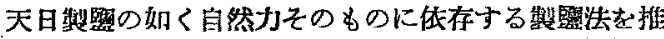

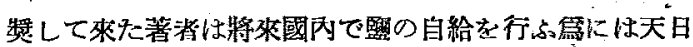

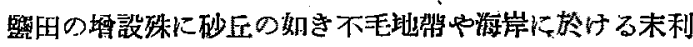

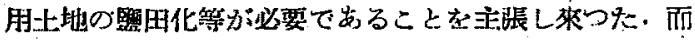

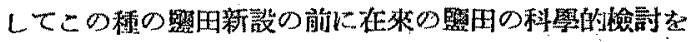
行ひ，これが $100 \%$ 能霖を發挥せしむることが現下の

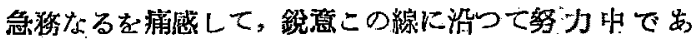

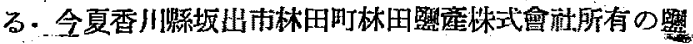

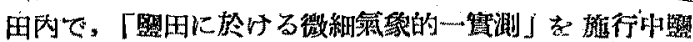

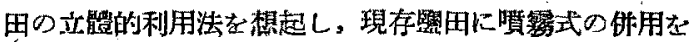

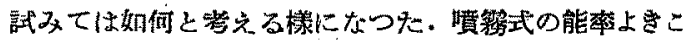

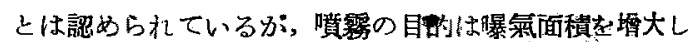

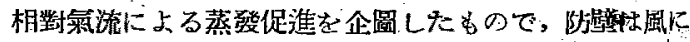
上る挰失を防がルとしてかへつて能弯の低下を計つてる ることになる・整田に於ける噴整式の件用では，この心

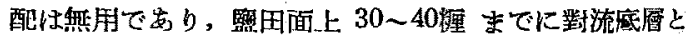
程すべき厤が存在しこれが蒸發及放熱を支配してみる

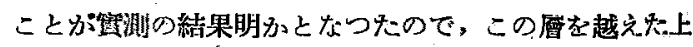

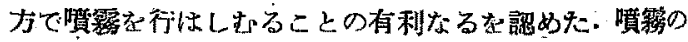

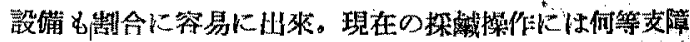

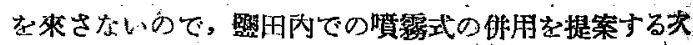

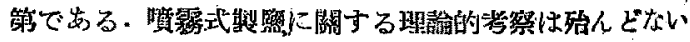

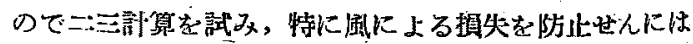

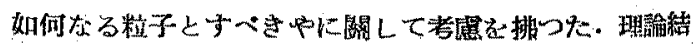
果の大要は次の如くである。 


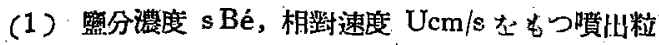

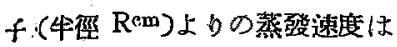

$$
\begin{aligned}
Q= & -4 \pi R \cdot \Delta \cdot\left(C_{s}-C_{0}\right)\left(1-0.045 S^{2 / 3}\right) \\
& \left(i+\frac{0.276}{\sqrt[3]{\sigma}} \sqrt{R_{e}}\right)
\end{aligned}
$$

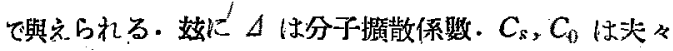

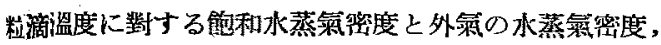

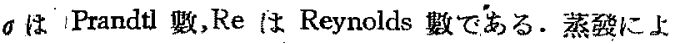

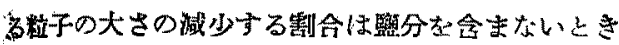

$$
\left(\frac{R}{R_{0}}\right)^{2}=1-\frac{2 \Delta\left(C_{s}-C_{0}\right)}{\rho R_{0}^{2}} t
$$

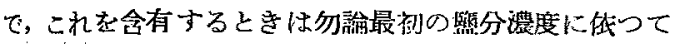
異なる゙沂似的に

$$
\left(\frac{R}{R_{0}}\right)=1-\frac{\Delta\left(C_{i s}-C_{0}\right)}{-\rho R_{0}^{2}} t
$$

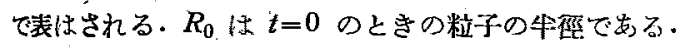

(2) $10^{-2}<R<0.2^{\mathrm{en}}$ 程度の粒子が自由落下すると きの終速既は $\quad U_{\infty}=\sqrt{\frac{8}{3} \frac{g}{C} \cdot \frac{\rho}{\rho_{a}} R}$

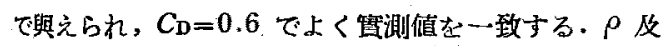
P $a$ は夫火液內茎氣の密度である。

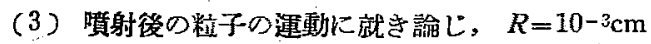

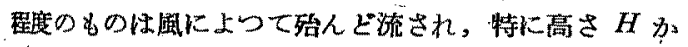

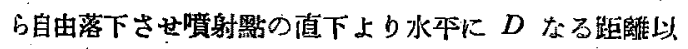
內に落下させるためには，

$$
R=\sqrt{\frac{9}{2}} \frac{\nu}{g} \frac{P a}{\rho} \frac{H U}{D}
$$

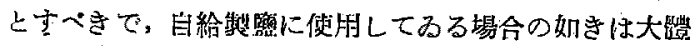
$R=2 \times 10^{-2} \mathrm{~cm}$ 程度とすればよいここが判る。

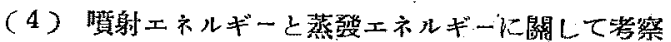

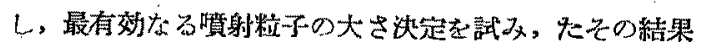

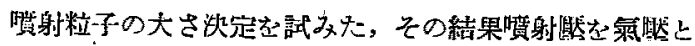
ナれば， $R=1 \mu$ 程度のものが最良でをることが物つれ

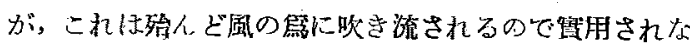
w.

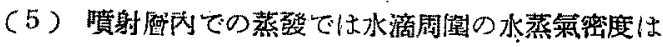

$$
\frac{C-C_{s}}{C_{0}-C_{z}}=e^{--\frac{3\lrcorner F w}{\rho v R^{2}} x}
$$

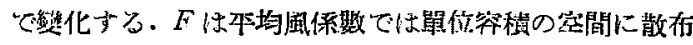

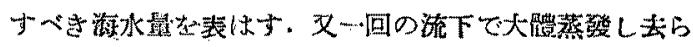
せるためには

$$
R=1.8 \times 10^{-7}\left(C_{s}-C_{0}\right) H
$$

程度よすの゙きて，この場命には大約 $2 \sim 3<10-2 \mathrm{~cm}$ とす

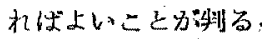

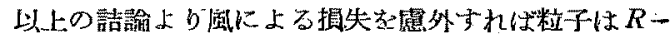
数 $\mu$ 程度で小さい程よいことになるが，望際には，こ れを計算に入れて $R=2 \times 10^{-2} \mathrm{~cm}$ 程度 の粒子とすべ でまらら。

竐:

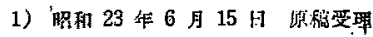

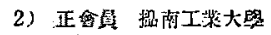

\section{彈性常數の一樣でない床の上におかれた梁の强度}

\section{鬼 頭 史 城2}

\section{On the Bending strength of a Beam placed upon}

a Bed having non- miform wasticity.

by Fumiki Kito;

彈性をむつた床のトにのせてぬるこころの梁の釣合い を表方方方程式は

$$
\frac{d^{2}}{d x^{2}}\left(E I \frac{d^{2} y}{d x^{2}}\right)+K y=0
$$

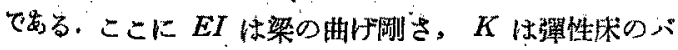

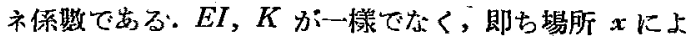
つて罣る埸合はいろいろ起り得る。ここではその最も簡

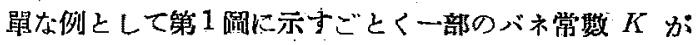

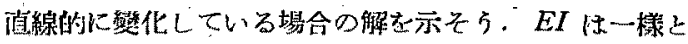

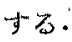

